Federal Reserve Bank of Dallas

Globalization and Monetary Policy Institute

Working Paper No. 300

https://www.dallasfed.org/ /media/documents/institute/wpapers/2017/0300.pdf

\title{
The Globalisation of Inflation: the Growing Importance of Global Value Chains ${ }^{*}$
}

\author{
Raphael Auer \\ Bank for International Settlements \\ Claudio Borio \\ Bank for International Settlements \\ Andrew Filardo \\ Bank for International Settlements
}

January 2017

\begin{abstract}
Greater international economic interconnectedness over recent decades has been changing inflation dynamics. This paper presents evidence that the expansion of global value chains (GVCs), ie cross-border trade in intermediate goods and services, is an important channel through which global economic slack influences domestic inflation. In particular, we document the extent to which the growth in GVCs explains the established empirical correlation between global economic slack and national inflation rates, both across countries and over time. Accounting for the role of GVCs, we also find that the conventional tradebased measures of openness used in previous studies are poor proxies for this transmission channel. The results support the hypothesis that as GVCs expand, direct and indirect competition among economies increases, making domestic inflation more sensitive to the global output gap. This can affect the trade-offs that central banks face when managing inflation.
\end{abstract}

JEL codes: E31, E52, E58, F02, F41, F42, F14, F62

\footnotetext{
* Raphael Auer, Bank for International Settlements, Centralbahnplatz 2, CH - 4002 Basel, Swizerland. raphael.auer@gmail.com. Claudio Borio, Bank for International Settmements, Centralbahnplatz 2, CH - 4002, Basel Switzerland. claudio.borio@bis.org. Andrew Filardo, Bank for International Settlements, Centralbahnplatz 2, CH - 4002 Basel, Switzerland. 41-61-280-8538. We thank Richard Baldwin, Andrew Bernard, Luca Dedola, Yi Huang, Filippo di Mauro, Michael Ehrmann, Enrique Martínez-García, Beata Javorcik, Robert Johnson, Jonathan Kearns, Andrei Levchenko, Marco Lombardi, Giovanni Lombardo, Chiara Osbat, Nikhil Patel, Ugo Panizza, Philip Sauré, Livio Stracca, Cédric Tille, Kenneth West and Mark Wynne for comments and suggestions. We also thank seminar participants at the BIS, the ECB, the ECB COMPNET-Czech National Bank Conference (on "Productivity and External Rebalancing"), the Federal Reserve Bank of Dallas and the Graduate Institute of International and Development Studies for additional comments and suggestions. Last, we are grateful to Andrea Civelli and Robert Johnson for sharing their data and codes with us. The views in this paper are those of the authors and do not necessarily reflect the views of the Bank for International Settlements, the Federal Reserve Bank of Dallas or the Federal Reserve System.
} 


\section{Introduction}

At the heart of the globalisation of inflation (GI) hypothesis is the view that the factors influencing domestic inflation have become increasingly global. One implication of this hypothesis is that global, and not just domestic, measures of economic slack should be relevant determinants of domestic inflation and that their role should have increased with global economic integration (eg Borio and Filardo (2007)). This more "globe-centric" view of the inflation process stands in contrast to traditional, "country-centric", characterisations, in which a Phillips curve relates a purely domestic output gap to domestic inflation.

Because of its far-reaching implications for our understanding of inflation and the conduct of monetary policy, the GI hypothesis has attracted considerable attention. The hypothesis was hotly debated already before the Great Financial Crisis (GFC) of 2007-2009 (Bean (2006), Fisher (2006), Yellen (2006) and Bernanke (2007)), and has become even more prominent since (Caruana (2012), Carney (2015), Fischer (2015), Jordan (2015), Draghi (2016) and Poloz (2016)). ${ }^{2}$

While it is generally agreed that domestic inflation rates have been co-moving more closely (Ciccarelli and Mojon (2010)), the correct interpretation of this finding hinges on the validity of the GI hypothesis. Proponents argue that tighter comovements reflect, in particular, the growing structural integration of goods and labour markets. This would, for instance, propagate national cost shocks more widely and strongly. By contrast, sceptics place greater weight on common policies. The empirical evidence so far has not yielded conclusive results. ${ }^{3}$

In this paper, we attempt to extend the literature on globalisation and inflation by exploring the role that the growth of global value chains (GVCs) can play in explaining the increasingly global nature of domestic inflation. The growth of GVCs during the past several decades reflects the international integration of more geographically fragmented global production processes, made possible by new technologies and lower trade barriers. One would expect this expansion to lead to a generalised increase in international competitive pressures ${ }^{4}$ and to weaken the relevance of purely national resource constraints on the inflation process.

To assess this hypothesis, we evaluate the extent to which various proxies for GVCs explain the relative importance of global and domestic measures of slack in influencing domestic inflation. We do so in a panel setting, thereby exploring the relevance of GVCs both across countries and over time. To track the growth of GVCs,

2 For the monetary policy modelling of related phenomena, see, for example, Benigno and Faia (2016), Engel (2013), Galí (2010), Martínez-García and Wynne (2010, 2013) and Woodford (2010).

3 See Borio and Filardo (2007), Ihrig et al (2010), Auer and Sauré (2013), Bianchi and Civelli (2015) and Manopimoke (2016), as well as the overview in Wynne (2012). This research is related to studies of the global co-movement of inflation (Mumtaz and Surico (2009, 2012), and Ciccarelli and Mojon (2010)).

$4 \quad$ GVCs can play a role in influencing inflation both directly and indirectly. A direct channel operates through greater import competition for intermediate goods and services. An indirect one works through greater international contestability, eg the threat of entry at the various stages of production. In turn, greater interconnectedness, and hence competition across countries at each stage of production, means that slack in one country will allow firms to alter their sourcing decisions, thereby reducing the pricing impact of any one country's slack conditions on the price of final goods and services. 
we consider total trade and its major components, focusing in particular on intermediate goods and services. To measure the influence of global and domestic slack on inflation, we rely on the published estimates of Bianchi and Civelli (2015) estimates that are in the spirit of the analysis of Borio and Filardo (2007). That recent paper provides estimates that capture greater time variation (annual estimates for each country) and cover a wider range of countries than the earlier paper. We exclude the GFC period and its aftermath owing to the powerful balance sheet dynamics that appear to dominate the typical cyclical forces.

We find that GVCs are a key to explaining the influence of global factors on domestic inflation. There is statistically significant evidence that the growth of international input-output linkages explains the increasing sensitivity of domestic inflation to global factors. This is the case both across countries and over time. The growth of GVCs is associated with both a reduction of the impact of domestic slack on domestic inflation and an increase in that of its global counterpart. ${ }^{5}$ Moreover, once the role of GVCs is taken into account, we find that the conventional measure of trade openness so extensively used in the literature, based on the aggregate volume of trade in goods and services, has only limited explanatory power for the link between globalisation and domestic inflation.

The paper proceeds as follows. The first section briefly describes the evolution of international input-output linkages and explores their possible link with inflation. The second section outlines the methodology for constructing measures of GVCs and of global slack's influence on domestic inflation. The third section examines the extent to which the growth of GVCs has influenced the relationship between global slack and domestic inflation, both across countries and over time. The conclusion raises some broader issues for policy and future research.

\section{GVCs and the internationalisation of the production process}

In recent decades, the growth of GVCs has been transforming business models of international production and trade. Graph 1 shows that the value added of imports of goods and services as a share of exports of goods and services rose from $18 \%$ in 1990 to around $25 \%$ in 2015. To be sure, the outsourcing and offshoring of production are not entirely new phenomena. Even so, they have intensified over the last twenty years, although they appear to have plateaued more recently.

The industrial organisation underpinning the expansion of GVCs has evolved, too. Initially, GVCs arose from firms' foreign direct investment and within-firm trade across geographic borders. Growth in net international asset positions went hand-inhand with the increase in international input-output linkages. Over time, however, outsourcing and offshoring have taken on greater prominence. Advances in technology have enabled international supply chains to expand. It is now possible to coordinate and track just-in-time production through international supply chains

\footnotetext{
Using a structural analysis of global sectoral input-output trade networks, Auer et al (2016) find corroborating evidence of the role of GVCs in accounting for the international co-movement of producer price inflation.
} 
from start to finish, ie through all the different production stages, and by different firms located in geographically distant world regions. As a result, today's GVCs include international manufacturing giants, such as Apple, that do not own most of the manufacturing plants in their supply chains. ${ }^{6}$

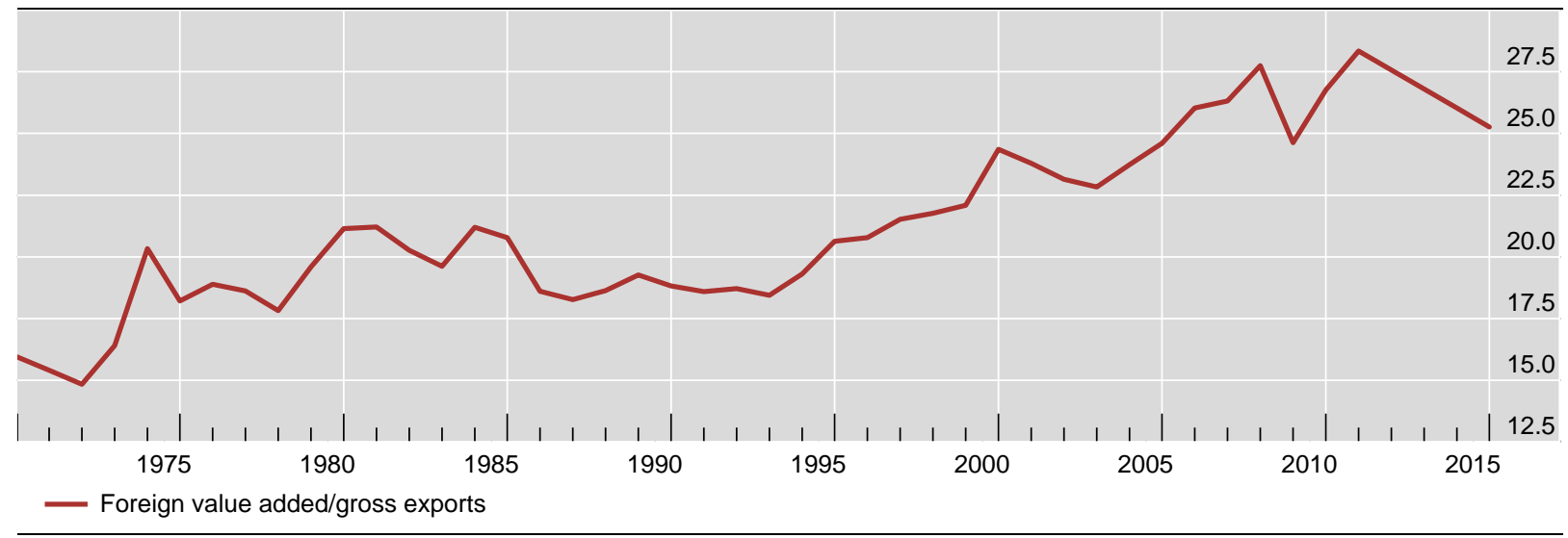

Sources: Johnson and Noguera (2016), OECD TIVA and ADB MRIO.

These developments represent a challenge to the classical assumptions behind the traditional country-centric view of trade and inflation determination. This view assumes that final goods and services are primarily differentiated in terms of the countries where they are produced. There is an implicit assumption that production supply chains are purely domestic. All this underpins the notion that domestic and foreign goods and services are highly imperfect substitutes and possibly priced in local currency. If so, country-specific demand pressures are naturally closely linked to domestic inflation, regardless of global conditions for the goods and services in question. The assumed limited mobility of domestic and foreign labour inputs further strengthens the link. Intra-national labour flows can relieve any sectoral bottlenecks within countries but cannot do so internationally.

The growth of GVCs challenges this traditional view by increasing the substitutability of the various production stages across borders. ${ }^{7}$ For inflation pressures, these developments imply that a mapping between country-specific excess demand and a country's inflation becomes less tight. At a minimum, the ability to shift stages of production geographically opens up opportunities to offset excess

6 Because of the way in which it affects the organisation of international production, the rise of GVCs has been referred to as the "second unbundling" (Baldwin (2014)). Its impact can be likened to the arrival of electric power in production processes. Power had been previously available to plants in the form of steam engines but it was difficult to distribute it throughout plants in a cost-effective manner. Electricity freed up this constraint: whereas in the past only a few of the stages of production could be efficiently driven by power shafts, electricity allowed the use of smaller motors that could be tailored to many more activities in a cost-effective way. In much the same way, GVCs have made it much easier to distribute the stages of production across the globe, thus greatly increasing the efficiency of global production.

7 To be sure, somewhat higher labour and capital mobility, and growing total trade in final goods and services contribute to greater cross-border contestability of factor and final goods markets. But arguably the possibility of shifting firm-specific know-how across borders and the ability to track all this along global supply chains have played a key role in further boosting the degree of substitutability. 
demand conditions in specific countries by redirecting some production to others where slack is present. Likewise, the price of factor inputs, such as domestic wages, and its relationship with the prices of domestic output are also influenced by supply conditions elsewhere. Global slack and bottlenecks become relevant for pricing both inputs and outputs.

The global view suggests that trade in final goods and services is an important, but incomplete, measure of openness and of the strength of the forces that make domestic markets contestable (Grossman and Rossi-Hansberg (2008)). For example, for a given level of exports and imports, greater global competition at each stage of production would result in more substitutability of factor inputs and outputs and hence raise the influence of global slack conditions at the expense of domestic ones. In this sense, trends in intermediate trade may be more informative about trends in global competition than the conventional measure based on the sum of all exports and imports (Lombardo and Ravenna (2014) and Burstein et al (2008)). ${ }^{8}$

\section{New measures of GVCs and of the relative strength of global slack on inflation}

Next, we consider in more detail the variables that form the basis of our empirical analysis, ie our proxies for GVCs and for global slack's impact on domestic inflation.

\section{Measures of trade openness}

The greater international fragmentation of production processes over the past decades suggests that conventional measures of trade openness may not be fully satisfactory. The most common openness measure used is the sum of official trade in imports and exports of goods and services, scaled by domestic output, or:

$$
\mathrm{CMTO}_{i, t}=\text { Conventional Measure of Trade Openness } \text { Ti,t }_{i \text {. }}=\frac{\text { imports }_{i, t}+\text { exports }_{i, t}}{G D P_{i, t}} .
$$

This measure includes trade in both intermediate and final goods and services. It features prominently in research on the topic of trade openness and the macroeconomy.

An alternative measure, which gives greater prominence to international supply chains, focuses on the imports and exports of intermediate goods and services. In the past, data to construct this alternative were difficult to compile for sufficiently long periods. Now, the data from Johnson and Noguera (2016) allow us to split trade in intermediate goods and services from the conventional measure of trade openness (CMTO):

8 In addition, of course, GVCs make exports and imports more complementary and help transmit price pressures directly across borders. 


$$
\begin{aligned}
& \mathrm{ITO}_{i, t}=\text { Intermediate Trade Openness }_{i, t}=\frac{\text { intemediate imports }_{i, t}+\text { intermediate exports }_{i, t}}{G D P_{i, t}} \\
& \mathrm{FTO}_{i, t}=\text { Final Trade Openness }{ }_{i, t}=\frac{\text { final imports }_{i, t}+\text { final exports }_{i, t}}{G D P_{i, t}} .
\end{aligned}
$$

Note that $C M T O_{i, t}=I T O_{i, t}+F T O_{i, t}$.

Our measure of intermediate trade openness can also be broken down into its subcomponents in order to consider whether intermediate exports or imports play the bigger role in accounting for the globalisation-inflation link:

$$
\begin{aligned}
E I O_{i, t} & =\text { Exported Intermediate Openness }_{i, t}=\frac{\text { intermediate exports }_{i, t}}{G D P_{i, t}} \\
I I O_{i, t} & =\text { Imported Intermediate Openness }_{i, t}=\frac{\text { intemediate imports }_{i, t}}{G D P_{i, t}}
\end{aligned}
$$

Finally, we consider two alternative measures of GVCs that have been proposed in the literature. The first is a proxy for the production cost channel of intermediate trade, the imported intermediate cost share (IICS) of production: ${ }^{9}$

$$
\operatorname{IICS}_{i, t}=\frac{\text { intermediate imports }}{i, t} \text {. }
$$

Note that the IICS and the imported intermediate openness (IIO) measures are closely related, but they differ because of differences in their denominators. IICS is scaled by production costs and $/ 1 O$ is scaled by GDP: whereas GDP includes only wages and profits, production costs also include the costs of imported and intermediate goods sourced domestically. In addition, these measures may overestimate the foreign component of the input costs. For example, within an automotive value chain, the United States exports both car engines and drive shafts to Mexico. If these parts are merely assembled and then shipped back to the United States, the US trade statistics will record substantial intermediate imports even though the Mexican value added embodied in these imports is small.

Another measure of GVCs featured in recent research is the domestic valueadded share of exports ("VAX"), proposed by Johnson and Noguera (2012). The VAX is the ratio of the domestic value added contained in domestic exports divided by the nominal value of exports:

$$
V A X_{i, t}=\frac{\text { domestic value added of exports }_{i, t}}{\text { exports }_{i, t}}
$$

By design, VAX measures the value-added created in one country that eventually finds its way into final demand in other countries (as a share of the nominal value of exports). For a given level of exports, greater integration into global value chains is associated with a lower $V A X$ - that is, the greater the fragmentation of international supply chains, the smaller the domestic value added in a country's exports and the greater the foreign value added. This suggests that the $V A X$ would be negatively correlated with the growth of GVCs.

9 This channel is examined in Auer and Mehrotra (2014), who argue that a firm's pricing decision depends closely on the cost share of that input in total production costs. They then document that import price fluctuations are transmitted more strongly into domestic prices in sectors with a higher cost share of imported intermediate goods and services. 
Table 1 presents summary statistics for these GVC indicators as well as their pairwise correlations. ${ }^{10}$ As expected, all the measures of trade openness are positively correlated with each other except for the $V A X$, which is negatively correlated with the rest. The appendix plots the evolution of ITO and FTO (Graph A1), and IICS and VAX (Graph A2).

Summary statistics

Table 1

\begin{tabular}{|c|c|c|c|c|}
\hline Variable & Mean & Std. Dev & Min & Max \\
\hline СМТО & 0.602 & 0.296 & 0.160 & 1.835 \\
\hline FTO & 0.284 & 0.132 & 0.084 & 0.723 \\
\hline ITO & 0.318 & 0.169 & 0.076 & 1.175 \\
\hline 110 & 0.174 & 0.092 & 0.041 & 0.598 \\
\hline EIO & 0.144 & 0.082 & 0.031 & 0.577 \\
\hline IICS & 0.089 & 0.045 & 0.022 & 0.276 \\
\hline VAX & 0.788 & 0.078 & 0.548 & 0.940 \\
\hline
\end{tabular}

Pairwise correlations

\begin{tabular}{lllllll}
\hline & CMTO & FTO & ITO & IIO & EIO & IICS \\
\hline CMTO & 1 & & & & & \\
\hline FTO & 0.802 & 1 & & & & \\
\hline ITO & 0.936 & 0.541 & 1 & & & \\
\hline$I I O$ & 0.927 & 0.657 & 0.918 & 1 & & \\
\hline EIO & 0.795 & 0.338 & 0.920 & 0.690 & 1 & 1 \\
IICS & 0.914 & 0.654 & 0.902 & 0.989 & 0.670 & -0.935 \\
\hline VAX & -0.826 & -0.626 & -0.795 & -0.920 & -0.544 & \\
\hline
\end{tabular}

Notes: $C M T O=$ (exports + imports of goods and services) $/ G D P, F T O=($ exports + imports of finals goods and services) $/ G D P, I T O=($ exports + imports of intermediate goods and services)/GDP, $I I O=$ (imports of intermediate goods and services) $/ G D P$, and EIO $=$ (exports of intermediate goods and services)/GDP. VAX is the domestic value-added of exports and IICS is the production cost share of imported intermediate goods and services (these measures are described in detail in Section 2).

\section{Measures of the globalisation-domestic inflation link}

The metric capturing the globalisation-inflation link is in the spirit of the analysis of Borio and Filardo (2007), which augments a traditional model of inflation with a measure of global slack.

Specifically, the regression we use here relates domestic inflation in country $i$ at time $t_{1} \pi_{i, t}$, to expected future inflation $E_{t}\left[\pi_{i, t+1}\right]$, the domestic output gap $y_{i, t}^{d}$ the global output gap $y_{i, t}^{f}$ a set of covariates $\mathrm{X}_{i, t}$, and the error term $\varepsilon_{i, t}$ :

$$
\pi_{i, t}=\alpha * E_{t}\left[\pi_{i, t+1}\right]+\beta * y_{i, t}^{d}+\gamma * y_{i, t}^{f}+\mathrm{X}_{i, t}+\varepsilon_{i, t} .
$$

In equation (1), the global gap for country $i, y_{i, t^{\prime}}^{f}$ is defined as the trade-weighted slack in all other countries (using weights $\left.\omega_{i, i}\right), y_{i, t}^{f}=\sum_{j \neq i} \omega_{i, j} y_{j, t}^{d}$, rather than as a global measure as such. This tailors the indicator of global slack to individual

10 The estimations below include country fixed effects. Thus, the coefficients are identified through the variation over time of the variables within each group. Accordingly, Table 1 focuses on correlations of changes rather than of levels. 
economies. And especially for the large countries, it should help further reduce any correlation with the domestic measure of slack, thereby helping to distinguish between the influences of the two measures. The coefficients of interest are $\beta$, the sensitivity of inflation with respect to the domestic output gap, and $\gamma$, its sensitivity with respect to the global output gap.

In this study, we rely on the coefficient estimates of equation (1) from Bianchi and Civelli (2015). The authors estimate a regression for the sample period ranging from 1982 to 2006 with quarterly panel data from 18 advanced and emerging market economies (EMEs). ${ }^{11}$ The estimation yields coefficient estimates for $\beta$ and $\gamma \cdot{ }^{12}$ The time-varying nature of the estimation yields a panel dataset of coefficients reflecting the estimated impact of global and domestic slack on domestic inflation that varies both across countries and over time.

The GI hypothesis postulates that the impact of domestic slack on inflation has waned over time (lower $\beta$ ), whereas that of global slack has risen (higher $\gamma$ ). To capture this in a single index, we define the Relative Global Factor:

$$
R G F_{i, t}=\text { Relative Global Factor }{ }_{i, t}=\gamma_{i, t}-\beta_{i, t}
$$

where $\gamma_{i, t}$ and $\beta_{i, t}$ are, respectively, the coefficients measuring the extent to which global and domestic slack affect domestic inflation in country $i$ at time $t$.

\section{Estimation and results}

We now turn to examining the empirical relationship between the relative strength of global slack's influence on domestic inflation (RGF) and intermediate trade openness.

Our baseline specification relates the conventional trade openness measure $\left(C M T O_{i, t}\right)$ to $R G F$, a relationship that was analysed in previous research on globalisation and inflation. In order to abstract from (non-time varying) cross-country differences and common trends, we include both country fixed effects and a trend. The specification is:

$$
R G F_{i, t}=\alpha_{i}+\delta_{\text {СмTO }} * C M T O_{i, t}+\delta_{\text {trend }} * \text { Quarter }+\varepsilon_{i, t} .
$$

The dependent variable is $R G F$ (ie $\gamma_{i, t}-\beta_{i, t}$ ) for a sample of 18 countries and Quarter is a time dummy. Given that $R G F$ is a generated regressor, conventionally

11 We rely on these estimates for three main reasons. First, they cover a wide set of countries. Second, the approach yields a panel set of estimated coefficients that can be readily used in our empirical approach. Third, the previous research did not optimise the approach to capture the role of GVCs and our use of the estimates avoids possible concerns of pre-test bias. Refining the estimates of the impact of global slack on domestic inflation based on GVC considerations is left for future research.

12 More specifically, these coefficients are obtained for each country separately from a time-varying VAR estimation of the form $\mathrm{X}_{i, t}=\mathrm{a}_{i, t}+\sum_{p=1}^{2} \mathrm{~B}_{i, \mathrm{t}, p} \mathrm{X}_{i, t-p}+\varepsilon_{i, t}$. The vector of variables $\mathrm{X}_{i, t}=$ $\left[\mathrm{y}_{i, t}^{d}, \mathrm{y}_{i, t}^{f}, \pi_{i, t}, \tau_{i, t}, i_{i, t}\right]$ includes the domestic output gap $\mathrm{y}_{i, t}^{d}$, the global output gap $\mathrm{y}_{i, t^{\prime}}^{g}$ domestic inflation $\pi_{i, t}$, the real exchange rate $\tau_{i, t}$ as a proxy for import price inflation and the domestic interest rate $i_{i, t}$. The reduced-form coefficients are identified via a Cholesky decomposition assuming the following ordering of the variables: $\mathrm{y}_{i, t}^{f}, \mathrm{y}_{i, t}^{d}, \pi_{i, t}, \tau_{i, t}, i_{i, t}$. 
estimated standard errors can be biased. We address this possibility by reporting bootstrapped standard errors. ${ }^{13}$

Our strategy then is to see whether our measures of GVCs help improve the baseline regression and allow us to detect an influence of global slack.

\section{Assessing the importance of intermediate and final trade openness}

The panel regression results of Equation (2) are reported in column 1 of Table 2. The estimates of this benchmark specification indicate a positive correlation between trade openness (as measured by CMTO) and the relative strength of global slack on inflation (RGF). This result seemingly confirms the view found in the literature that expanding trade openness goes hand-in-hand with a growing importance of globalisation for inflation.

RGF panel regressions: comparing the explanatory power of CMTO, ITO and FTO

Table 2

(1) (2) (3)

Dependent variable: relative global factor $(R G F)$

\begin{tabular}{lc}
\hline CMTO & $0.78^{\star \star *}$ \\
& {$[0.143]$}
\end{tabular}

ITO

FTO

Orthogonalised ITO (vis-à-vis ITO and FTO)

Model information

\begin{tabular}{|c|c|c|c|}
\hline Trend & $\mathrm{Y}$ & $\mathrm{Y}$ & $Y^{\dagger}$ \\
\hline Fixed effects & $Y$ & $\mathrm{Y}$ & $\mathrm{Y}$ \\
\hline Common factor & & & $\mathrm{Y}$ \\
\hline $\mathrm{R}^{2}$ & 0.071 & 0.089 & 0.089 \\
\hline Observations & 1,800 & 1,800 & 1,800 \\
\hline Number of countries & 18 & 18 & 18 \\
\hline \multicolumn{4}{|c|}{$\begin{array}{l}\text { Notes: in all specifications, the dependent variable is the standardised value of RGF and the sample runs from Q1 } 1982 \text { to Q4 } \\
\text { 2006. In column } 1 \text {, the independent variable, CMTO, is the standardised value of (exports + imports)/GDP. In column 2, the } \\
\text { independent variables are the standardised values of FTO = (exports + imports of finals goods and services)/GDP and ITO = } \\
\text { (exports + imports of intermediate goods and services)/GDP. In column 3, "Orthogonalised ITO" is the error term from a } \\
\text { regression of ITO on the first principal component of a trend, ITO and FTO, and the "Orthogonalised FTO" is the error term from } \\
\text { a regression of FTO on the first principal component of a trend, ITO and FTO. The first principal component is included in the } \\
\text { regression (coefficient not reported). Bootstrapped standard errors reported in brackets; }{ }^{* * *} \text { denotes significance at the } 1 \% \\
\text { level, ** at the } 5 \% \text { level, and * at the } 10 \% \text { level. }{ }^{\dagger} \text { The trend is included in the principle component analysis. }\end{array}$} \\
\hline
\end{tabular}

13 In all the specifications considered in Table 1 , the independent and dependent variables are standardised (ie transformed to have zero mean and a unit standard deviation) in order to simplify the comparability of coefficient sizes across specifications. 
To investigate whether GVC-related intermediate or final trade matters more for the GI hypothesis, we first split the CMTO trade openness variable into intermediate (ITO) and final trade openness (FTO). Rewriting Equation (2) to reflect this yields a regression of the form:

$$
R G F_{i, t}=\alpha_{i}+\delta_{\text {ITO }} * I T O_{i, t}+\delta_{F T O} * F T O_{i, t}+\delta_{\text {trend }} * \text { Quarter }+\varepsilon_{i, t}
$$

We find that the growth of trade in intermediate goods and services is the main driver of the statistical relationship between trade openness and $R G F$ in our sample. The regression results presented in column 2 of Table 2 show that the intermediate trade ITO variable is statistically significant and positively correlated with RGF. The coefficient on final trade openness FTO is statistically insignificant at the $5 \%$ level and, in fact, negative.

Addressing possible collinearity between ITO and FTO does not alter this conclusion. Note that ITO and FTO are highly correlated both across time and across countries. We control for this correlation by first extracting the common component of a trend, ITO and FTO via principal component analysis. We then include this common component in the regressions (coefficient not reported) alongside the orthogonalised components of ITO and FTO in column 3 of Table 2. Both coefficients are statistically significant and positive but the coefficient estimate of 1.26 for $\delta_{\text {ITO }}$ is much larger than 0.29 for $\delta_{F T O}$. In other words, intermediate trade matters more than final trade when accounting for developments in RGF. To get a sense of the quantitative importance, assume that an economy experiences a 10-percentage point rise in intermediate trade (as a share of GDP). Our estimates would indicate a 0.87 percentage point increase in the sensitivity of domestic inflation to the global output gap. In terms of inflation, if the global gap is 1.0, inflation would be higher by 0.87 percentage point. ${ }^{14}$

Simple graphical evidence confirms the statistical significance of ITO. The correlations between ITO and RGF reported in Graphs 2 and 3 support the case for the link between intermediate trade and the impact of globalisation on inflation both across countries and over time. Graph 2 shows the cross-sectional relationship of ITO and RGF for 18 countries from 1982-2006. The $\mathrm{x}$-axis shows the country averages of the ITO; the $y$-axis the averages of RGF. The relationship is positive and statistically significant at the $5 \%$ level. Similarly, Graph 3 plots the evolution of the cross-country average ITO and RGF over time. The graph indicates a positive relationship that is statistically significant at the $1 \%$ level.

Overall, the statistical and graphical evidence support the view that countries more integrated into international supply chains experience a greater sensitivity of domestic inflation to global factors. And as GVCs have grown over time, the influence of global slack on domestic inflation has increased relative to its domestic counterpart. The GVC measures appear to capture much better the influence of global slack than the conventional aggregate trade openness indicator.

14 The estimate of 0.87 is based on the following calculation, which takes into account our standardisation of the variables included in the regression. We first scale the $10 \%$ change in intermediate trade by its standardisation factor (ie the standard deviation of ITO of 0.318) before multiplying it by the estimated coefficient $\delta_{\text {ITO }}: 1.26^{*}(0.10 / 0.318) \approx 0.4$ in units of a standardised $R G F$. In turn, with a standard deviation of $R G F$ of 2.17 , the $10 \%$ change implies a $0.4 * 2.17 \approx 0.87$ change in $\gamma-\beta$. For inflation, we assume for simplicity that the change comes entirely through $\gamma$. 


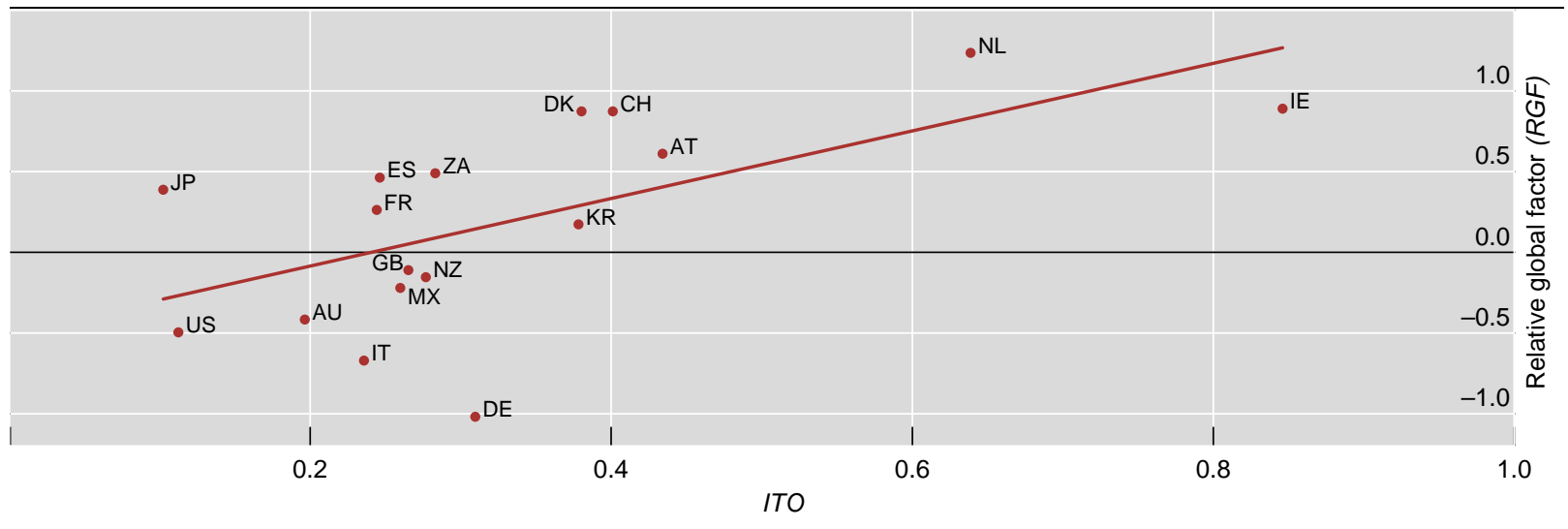

$\mathrm{AU}=$ Australia; $\mathrm{AT}=$ Austria; $\mathrm{CH}=$ Switzerland; $\mathrm{DE}=$ Germany; $\mathrm{DK}=$ Denmark; $\mathrm{ES}=$ Spain; FR = France; $\mathrm{GB}=$ United Kingdom; $\mathrm{IE}=$ Ireland; $\mathrm{IT}=$ Italy; JP = Japan; KR = Korea; MX = Mexico; NL = Netherland; NZ = New Zealand; US = United States; ZA = South Africa

1 The cross-country relationship between ITO $=$ (exports + imports of intermediate goods and services)/GDP and the relative global factor (RGF) for 17 economies. Each observation shows the sample average over time (1982-2006) of ITO and RGF. The red fitted line has a slope of 2.09 (significant at the $1 \%$ level). Canada $(R G F=-3.17, I T O=0.40)$ is not included.

Source: authors' calculations.

GVCs and the explanatory power of global output gaps over time ${ }^{1}$

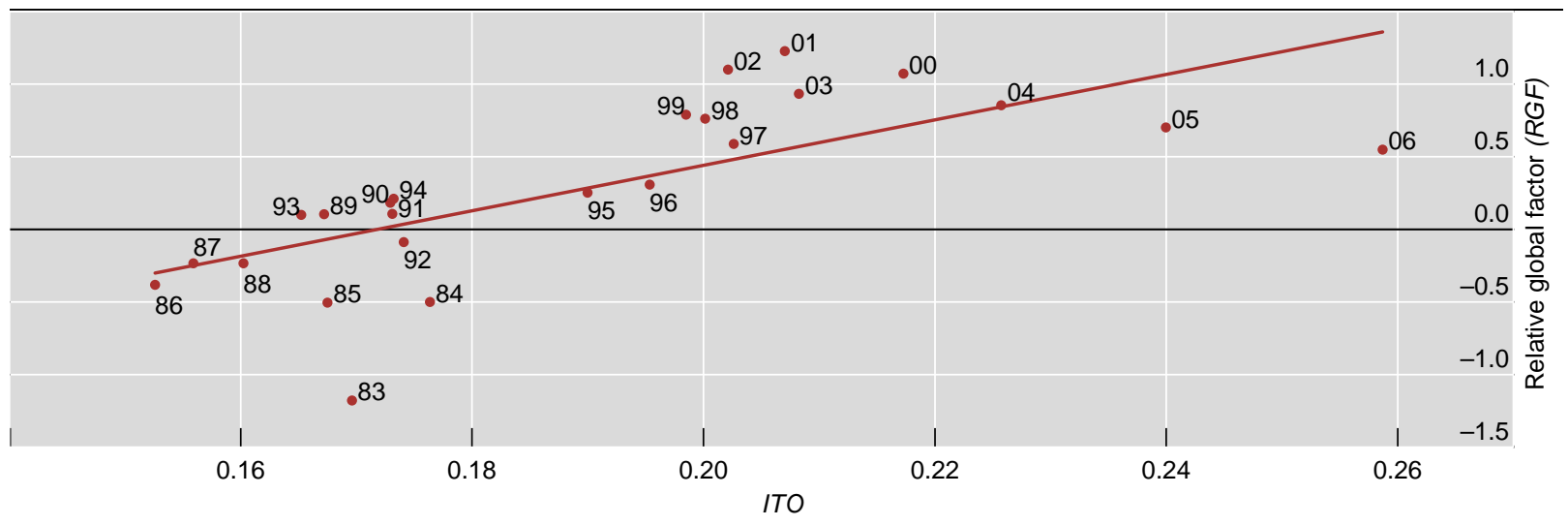

1 The relationship between ITO = (exports + imports of intermediate goods and services)/GDP and the relative global factor ( $R G F$ ) for the years from 1983 to 2006 . Each observation shows the cross-country average of ITO and RGF in a given year for 18 countries. The red fitted line has a slope of 15.6 (significant at the 1\% level).

Source: authors' calculations.

\section{Digging further into GVC-related trade data}

The statistical significance of total intermediate trade raises the question of whether a separate consideration of intermediate exports and imports could yield further insights. Table 3 explores this possibility with our panel regression approach. The table also includes the results using alternative GVC-related trade measures: IICS and VAX. 


$\begin{array}{cc}11 O & 0.70^{\star \star \star *} \\ & {[0.150]} \\ \text { EIO } & 0.17 \\ & {[0.170]}\end{array}$

Orthogonalised $/ / O$ (vis-à-vis $/ / O$ and $E / O$ )

Orthogonalised $E I O$ (vis-à-vis $/ / O$ and $E I O)$

Orthogonalised IICS (vis-à-vis IIO, EIO, I/CS)

Orthogonalised $/ / O$ (vis-à-vis /IO, EIO, IICS)

Orthogonalised EIO (vis-à-vis //O, EIO, I/CS)

Orthogonalised VAX (vis-à-vis IIO, EIO, VAX)

Orthogonalised $I / O$ (vis-à-vis $/ I, E I O, V A X)$

Orthogonalised EIO (vis-à-vis IIO, EIO, VAX) $1.15^{\star \star *}$

[0.09]

$0.63^{*}$

[0.32]
0.17

[0.322]

1.80 ***

0.13

[0.181]

Model information

\begin{tabular}{lcccc}
\hline FTO & $\mathrm{Y}$ & $\mathrm{Y}$ & $\mathrm{Y}$ & $\mathrm{Y}$ \\
Trend (quarters) & $\mathrm{Y}$ & $\mathrm{Y}^{\dagger}$ & $\mathrm{Y}^{\dagger}$ & $\mathrm{Y}^{\dagger}$ \\
Fixed effects & $\mathrm{Y}$ & $\mathrm{Y}$ & $\mathrm{Y}$ & $\mathrm{Y}$ \\
Common factor & & $\mathrm{Y}$ & $\mathrm{Y}$ & $\mathrm{Y}$ \\
\hline $\mathrm{R}^{2}$ & 0.094 & 0.094 & 0.096 & 1,094 \\
Observations & 1,800 & 1,800 & 1,800 & 1800 \\
Number of countries & 18 & 18 & 18 \\
\hline
\end{tabular}

Notes: as defined in Section 2 of the paper, VAX is the value-added of exports, IICS is the production cost share of imported intermediate goods and services, ITO $=$ (exports + imports of intermediate goods and services) $/ G D P, I I O=$ (imports of intermediate goods and services)/GDP, and $E I O=$ (imports of intermediate goods and services)/GDP. For column 2, the first principal component of a trend, IIO and $E I O$ is constructed in a first but non-reported step. The orthogonal element of $I / O$ and $E I O$ to this first principal common component is then included as an independent variable in column 3; the first principal component is also included in the regression (coefficient not reported). The same procedure is followed to examine the partial effects of $I I C S, I I O$ and $E I O$ in column 3, and of VAX, IIO and EIO in column 4. In all specifications, the dependent variable is the standardised value of $R G F$ and the sample includes data from Q1 1982 to Q4 2006. Bootstrapped standard errors in brackets; ${ }^{* *}$ denotes significance at the $1 \%$ level, ${ }^{* \star}$ at the $5 \%$ level, and * at the $10 \%$ level. ${ }^{\dagger}$ The trend is included in the principle component analysis.

The evidence presented in Table 3 shows that intermediate imports and, to a lesser extent, intermediate exports help explain the relationship between global slack and inflation. In specification (1), both imported intermediate goods and services, IIO, and exported intermediate goods and services, EIO, are included as regressors. (This specification also includes final trade openness, FTO, as an independent variable (coefficient not reported)). The $/ / O$ coefficient estimates are statistically significant and 
positive, and the $E I O$ estimates are statistically insignificant. Given the high correlation of these variables, specification (2) includes only the orthogonalised components of $I I O$ and $E I O$. The coefficient estimates on the variables are somewhat larger and both are statistically significant. Note that the coefficient size and statistical significance of IIO remain larger than that for $E I O$.

Adding the alternative GVC-related trade measures (ie IICS and VAX) to the RGF panel regressions with $I / O$ and $E I O$ nuances the interpretation of the relationship. With IICS (ie the orthogonalised version), specification (3) yields little evidence that the cost channel of imported production inputs explains the relationship; the coefficient on IICS is 0.13 and statistically insignificant. By contrast, the inclusion of VAX suggests that imported and exported intermediate trade both play a role; the negative sign on the coefficient is the expected one. Together with the orthogonalised $I / O$ and $E I O$, the joint significance of $V A X$ suggests that the extent of fragmentation and the volumes of trade flowing through each link in international supply chains matter.

In sum, Table 3 highlights the evidence for our second main finding. Intermediate imports and, to a lesser extent, intermediate exports and the value added share of exports provide additional explanatory power for developments in $R G F .{ }^{15}$

\section{Robustness}

In this subsection, we show that the conclusions derived from Tables 2 and 3 stand up to a battery of robustness checks.

In Table 4, we look further into the relationship between RGF and ITO, controlling for country characteristics, aggregate trends and fluctuations. We also consider different subsamples and the influence of outliers. Specifications (1) and (2) in Table 4 control for country-fixed and time-fixed effects and yield no discernible change in the statistical significance of the impact of ITO on RGF. Specification (3) restricts the sample to the subperiod starting in 1985 Q1, and specification (4) to that beginning in 1989 Q1. Compared with the full sample results (ie specification (2) in Table 2), there is some decline in the estimated size of the impact but that impact remains statistically significant. Note that the final trade openness variable FTO is included in all specifications as a control, as noted in the lower part of each table.

These conclusions hold also when outliers in the dependent or independent variables are excluded. Specification (5) excludes observations for which either the dependent variable RGF or the independent variable ITO is more than two standard deviations away from the mean. Specification (6) excludes Canada since the country is the only consistent outlier in terms of RGF. ITO remains economically and statistically significant.

15 Consistent with our conclusions that both imports and exports matter, in the appendix we construct a GVCl variable by combining information on the imported-input cost share of production, IICS, and the value added content of exports, VAX. In Graphs A3 and A4, we show that the resulting index can help explain the pattern of $R G F$ over time and across countries. Further analysis of this relationship is left for future research. 


\begin{tabular}{|c|c|c|c|c|c|c|c|c|}
\hline & $(1)$ & $(2)$ & (3) & (4) & (5) & (6) & (7) & (8) \\
\hline & $\begin{array}{l}\text { No } \\
\text { trend }\end{array}$ & $\begin{array}{l}\text { Time } \\
\text { fixed } \\
\text { effects }\end{array}$ & $\begin{array}{l}\text { Post- } \\
1984\end{array}$ & $\begin{array}{l}\text { Post- } \\
1989\end{array}$ & $\begin{array}{c}\text { Winsorised } \\
\text { variables }\end{array}$ & $\begin{array}{c}\text { w/o } \\
\text { Canada }\end{array}$ & $\begin{array}{l}\text { Financial } \\
\text { openness }\end{array}$ & $\begin{array}{l}\text { Orthogonalised } \\
\text { components }\end{array}$ \\
\hline ITO & $\begin{array}{l}0.71^{\star * \star} \\
{[0.130]}\end{array}$ & $\begin{array}{l}0.80^{* * *} \\
{[0.152]}\end{array}$ & $\begin{array}{l}0.49^{* * *} \\
{[0.084]}\end{array}$ & $\begin{array}{l}0.40^{* * *} \\
{[0.111]}\end{array}$ & $\begin{array}{l}0.54^{\star * *} \\
{[0.055]}\end{array}$ & $\begin{array}{l}0.80^{* * *} \\
{[0.134]}\end{array}$ & $\begin{array}{l}0.91^{* * *} \\
{[0.134]}\end{array}$ & \\
\hline $\begin{array}{l}\text { Financial openness } \\
(F O)\end{array}$ & & & & & & & $\begin{array}{r}-0.10^{\star \star *} \\
{[0.030]}\end{array}$ & \\
\hline $\begin{array}{l}\text { Orthogonalised ITO } \\
\text { (vis-à-vis ITO \& FO) }\end{array}$ & & & & & & & & $\begin{array}{l}1.06^{\star * *} \\
{[0.143]}\end{array}$ \\
\hline $\begin{array}{l}\text { Orthogonalised FO } \\
\text { (vis-à-vis ITO \& FO) }\end{array}$ & & & & & & & & $\begin{array}{l}0.22^{* * *} \\
{[0.060]}\end{array}$ \\
\hline \multicolumn{9}{|l|}{ Model information } \\
\hline FTO & Y & Y & Y & Y & Y & Y & Y & \\
\hline Trend & & & $\mathrm{Y}$ & Y & Y & Y & Y & $\mathrm{Y}^{\dagger}$ \\
\hline Fixed effects & $\mathrm{Y}$ & Y & Y & $\mathrm{Y}$ & Y & Y & Y & $\mathrm{Y}$ \\
\hline Time fixed effects & & Y & & & & & & \\
\hline Common factor & & & & & & & & Y \\
\hline $\mathrm{R}^{2}$ (overall) & 0.056 & 0.137 & 0.045 & 0.062 & 0.241 & 0.090 & 0.092 & 0.089 \\
\hline Observations & 1,800 & 1,800 & 1,566 & 1,206 & 1,639 & 1,700 & 1,800 & 1,800 \\
\hline $\begin{array}{l}\text { Number of } \\
\text { countries }\end{array}$ & 18 & 18 & 18 & 18 & 18 & 17 & 18 & 18 \\
\hline
\end{tabular}

Notes: $I T O=$ (exports + imports of intermediate goods and services)/GDP. In all columns, the dependent variable is the standardised value of RGF. Column 1 does not include a trend, while column 2 includes time-fixed effects. The sample is at a quarterly frequency from 1985 to 2006 in column 3, from 1990 to 2006 in column 4, and from 1982 to 2006 in the remaining columns. Column 5 excludes observations for which either the dependent or the independent variable exceeds more than two standard deviations from the mean. Column 6 excludes Canada from the sample. Column 7 includes financial openness (see main text for definition). Column 8 includes components of ITO and financial openness that are orthogonal to the first principal component of these two variables and a trend. The first principal component is also included in the regression (coefficient not reported). All estimations include group fixed effects. Bootstrapped standard errors reported in brackets. ${ }^{* *}$ denotes significance at the $1 \%$ level, ${ }^{* *}$ at the $5 \%$ level, and ${ }^{*}$ at the $10 \%$ level. ${ }^{\dagger}$ The trend is included in the principle component analysis.

We repeat this battery of robustness tests for RGF and IIO in Table 5, and for RGF and $V A X$ in Table 6. The conclusions are similar to those in Table 4.

The literature on globalisation and inflation also points to the possibility that financial openness may be responsible for greater international connectedness, which in turn helps explain the dynamics of domestic inflation. To explore this possibility, we add a conventional measure of financial openness into the mix. ${ }^{16}$ The estimation results in specifications (7)-(8) in Tables 4-6 indicate that financial openness cannot be the whole story. The positive and statistically significant coefficient on financial openness in specification (8) suggests that such openness may be having an effect on inflation dynamics but there is no evidence that it supplants or even dominates the effect of GVC-related trade.

16 Financial openness is measured as the ratio of the sum of international total assets and liabilities to GDP (taken from Lane and Milesi-Ferretti (2007)). 
$R G F$ panel regressions: robustness analysis for $1 / O$

Table 5

\begin{tabular}{|c|c|c|c|c|c|c|c|c|}
\hline & $\begin{array}{l}\text { (1) } \\
\text { No } \\
\text { trend }\end{array}$ & $\begin{array}{l}(2) \\
\text { Time fixed } \\
\text { effects }\end{array}$ & $\begin{array}{l}(3) \\
\text { Post- } \\
1984\end{array}$ & $\begin{array}{l}(4) \\
\text { Post- } \\
1989\end{array}$ & $\begin{array}{c}\text { (5) } \\
\text { Winsorised } \\
\text { variables }\end{array}$ & $\begin{array}{c}(6) \\
\text { w/o } \\
\text { Canada }\end{array}$ & $\begin{array}{c}\text { (7) } \\
\text { Financial } \\
\text { openness }\end{array}$ & $\begin{array}{l}\text { (8) } \\
\text { Orthogonalised } \\
\text { components }\end{array}$ \\
\hline 110 & $\begin{array}{l}0.88^{* * *} \\
{[0.134]}\end{array}$ & $\begin{array}{l}0.90 * * * \\
{[0.134]}\end{array}$ & $\begin{array}{l}0.53^{* * *} \\
{[0.086]}\end{array}$ & $\begin{array}{l}0.33^{\star * \star} \\
{[0.093]}\end{array}$ & $\begin{array}{l}0.68^{* * *} \\
{[0.054]}\end{array}$ & $\begin{array}{l}0.85^{\star * *} \\
{[0.129]}\end{array}$ & $\begin{array}{l}0.94^{* * *} \\
{[0.139]}\end{array}$ & \\
\hline $\begin{array}{l}\text { Financial openness } \\
(F O)\end{array}$ & & & & & & & $\begin{array}{l}-0.09^{*} \\
{[0.048]}\end{array}$ & \\
\hline $\begin{array}{l}\text { Orthogonalised IIO } \\
\text { (vis-à-vis IIO \& FO) }\end{array}$ & & & & & & & & $\begin{array}{l}0.95^{\star \star \star} \\
{[0.117]}\end{array}$ \\
\hline $\begin{array}{l}\text { Orthogonalised FO } \\
\text { (vis-à-vis IIO \& FO) } \\
\text { Model information }\end{array}$ & & & & & & & & $\begin{array}{c}0.16^{* *} \\
{[0.081]}\end{array}$ \\
\hline FTO & $\mathrm{Y}$ & Y & Y & Y & Y & Y & $Y$ & \\
\hline Trend & & & Y & Y & Y & Y & Y & $Y^{\dagger}$ \\
\hline Fixed effects & Y & Y & Y & Y & Y & $\mathrm{Y}$ & $\mathrm{Y}$ & $\mathrm{Y}$ \\
\hline Time fixed effects & & Y & & & & & & \\
\hline Common factor & & & & & & & & $\mathrm{Y}$ \\
\hline $\mathrm{R}^{2}$ (overall) & 0.078 & 0.145 & 0.045 & 0.038 & 0.289 & 0.093 & 0.094 & 0.088 \\
\hline Observations & 1,800 & 1,800 & 1,566 & 1,206 & 1,639 & 1,700 & 1,800 & 1,800 \\
\hline $\begin{array}{l}\text { Number of } \\
\text { countries }\end{array}$ & 18 & 18 & 18 & 18 & 18 & 17 & 18 & 18 \\
\hline
\end{tabular}

Notes: $/ / O=$ (imports of intermediate goods and services)/GDP. In all columns, the dependent variable is the standardised value of $R G F$. Column 1 does not include a trend, while column 2 includes time-fixed effects. The sample is at a quarterly frequency from 1985 to 2006 in column 3, from 1990 to 2006 in column 4, and from 1982 to 2006 in the remaining columns. Column 5 excludes observations for which either the dependent or the independent variable exceeds more than two standard deviations from the mean. Column 6 excludes Canada from the sample. Column 7 includes financial openness (see the main text for the definition). Column 8 includes components of $I / O$ and financial openness that are orthogonal to the first principal component of these two variables and a trend. The first principal component is included in the regression (coefficient not reported). All estimations include group fixed effects. Bootstrapped standard errors reported in brackets. ${ }^{* \star *}$ denotes significance at the $1 \%$ level, ${ }^{* \star}$ at the $5 \%$ level, and ${ }^{*}$ at the $10 \%$ level. ${ }^{\dagger}$ The trend is included in the principle component analysis. 


\begin{tabular}{|c|c|c|c|c|c|c|c|c|}
\hline & \multirow[b]{2}{*}{ No trend } & \multirow{2}{*}{$\begin{array}{c}(2) \\
\text { Time fixed } \\
\text { effects }\end{array}$} & \multirow{2}{*}{$\begin{array}{c}\text { (3) } \\
\text { Post-1984 }\end{array}$} & \multirow{2}{*}{$\begin{array}{c}\text { (4) } \\
\text { Post-1989 }\end{array}$} & \multirow{2}{*}{$\begin{array}{c}\text { (5) } \\
\text { Winsorised } \\
\text { variables }\end{array}$} & \multirow[b]{2}{*}{ w/o Canada } & \multirow{2}{*}{$\begin{array}{c}\text { (7) } \\
\text { Financial } \\
\text { openness }\end{array}$} & \multirow{2}{*}{$\begin{array}{c}\text { (8) } \\
\text { Orthogonalised } \\
\text { components }\end{array}$} \\
\hline & & & & & & & & \\
\hline VAX & $\begin{array}{c}-0.46^{* * *} \\
{[0.094]}\end{array}$ & $\begin{array}{c}-0.56^{\star * *} \\
{[0.121]}\end{array}$ & $\begin{array}{c}-0.37^{* * *} \\
{[0.116]}\end{array}$ & $\begin{array}{l}-0.05 \\
{[0.087]}\end{array}$ & $\begin{array}{c}-0.42^{* * *} \\
{[0.050]}\end{array}$ & $\begin{array}{c}-0.53^{\star * *} \\
{[0.138]}\end{array}$ & $\begin{array}{r}-0.51^{\star * *} \\
{[0.107]}\end{array}$ & \\
\hline $\begin{array}{l}\text { Financial } \\
\text { openness }(F O)\end{array}$ & & & & & & & $\begin{array}{l}-0.11^{\star *} \\
{[0.050]}\end{array}$ & \\
\hline $\begin{array}{l}\text { Orthogonalised } \\
V A X \text { (vis-à-vis } \\
V A X \& F O)\end{array}$ & & & & & & & & $\begin{array}{c}-0.74^{\star \star \star} \\
{[0.108]}\end{array}$ \\
\hline $\begin{array}{l}\text { Orthogonalised } \\
\text { FO (vis-à-vis } \\
V A X \& F O)\end{array}$ & & & & & & & & $\begin{array}{l}0.40^{* * *} \\
{[0.068]}\end{array}$ \\
\hline Model informatio & & & & & & & & \\
\hline FTO & $\mathrm{Y}$ & $\mathrm{Y}$ & Y & Y & Y & $\mathrm{Y}$ & Y & \\
\hline Trend & & & Y & Y & Y & Y & Y & $Y^{\dagger}$ \\
\hline Fixed effects & Y & Y & Y & Y & Y & Y & $\mathrm{Y}$ & $Y$ \\
\hline $\begin{array}{l}\text { Time fixed } \\
\text { effects }\end{array}$ & & Y & & & & & & \\
\hline Common factor & & & & & & & & $\mathrm{Y}$ \\
\hline $\mathrm{R}^{2}$ (overall) & 0.028 & 0.108 & 0.027 & 0.007 & 0.268 & 0.057 & 0.063 & 0.063 \\
\hline Observations & 1,800 & 1,800 & 1,566 & 1,206 & 1,639 & 1,700 & 1,800 & 1,800 \\
\hline $\begin{array}{l}\text { Number of } \\
\text { countries }\end{array}$ & 18 & 18 & 18 & 18 & 18 & 17 & 18 & 18 \\
\hline
\end{tabular}

Notes: $V A X=$ value added of exports. In all columns, the dependent variable is the standardised value of $R G F$. Column 1 does not include a trend, while column 2 includes time-fixed effects. The sample is at a quarterly frequency from 1985 to 2006 in column 3 , from 1990 to 2006 in column 4, and from 1982 to 2006 in the remaining columns. Column 5 excludes observations for which either the dependent or independent variable exceeds more than two standard deviations from the mean. Column 6 excludes Canada from the sample. Column 7 includes financial openness (see the main text for the definition). Column 8 includes components of VAX and financial openness orthogonal to the first principal component of these two variables and a trend. The first principal component is included in the regression (coefficient not reported). All estimations include group fixed effects. Bootstrapped standard errors reported in brackets. ${ }^{* \star *}$ denotes significance at the $1 \%$ level, ${ }^{* *}$ at the $5 \%$ level, and ${ }^{*}$ at the $10 \%$ level. ${ }^{\dagger}$ The trend is included in the principle component analysis.

A final set of robustness tests is reported in Table 7. These tests investigate the GI hypothesis using different measures of GVCs and two variants of the RGF variable - one that considers the separate influence of domestic and global slack in $R G F$, rather than using simply the difference between the two, and one that considers a long-run version of $R G F .^{17}$

Splitting RGF into its components, $\beta$ and $\gamma$, the panel regressions indicate that GVC-related trade influences each of these coefficients. The impact is both statistically significant and intuitive. Interestingly, $/ 1 O$ has a larger positive impact on $\gamma$ (the coefficient on the global output gap) than on $\beta$ (the coefficient on the domestic output gap). By contrast, VAX has a larger impact on $\beta$ than on $\gamma$. This suggests that

17 For example, from an underlying regression specification, $\pi_{t}=\alpha * \pi_{t-1}+\gamma_{1} * y_{t}^{f}+\gamma_{2} * y_{t-1}^{f}+\varepsilon_{t}$, the long-run equivalent of gamma, $\gamma^{L R}$, is equal to $\left(\gamma_{1}+\gamma_{2}\right) /(1-\alpha)$. 
intermediate import competition appears to be driven primarily by global factors, while export competition (as measured by the value added of domestic exports) is driven primarily by domestic factors. ${ }^{18}$

Specifications (7)-(9) in Table 7 consider the relationship of the long-run RGF and GVC-related trade. Instead of $\gamma-\beta$, which measures the period $t$ impact of the global and domestic output gaps on inflation, we define the long-run analogue $R G F^{L F}, \gamma^{L R}-$ $\beta^{L R}$, which takes account of the autoregressive nature of the estimated Phillips curves. In other words, the $R G F^{L R}$ measures the implied long-run impact associated with the respective output gaps. The panel regression results indicate that the GVCrelated measures are still statistically significant, especially $I I O$ and VAX.

\begin{tabular}{|c|c|c|c|c|c|c|c|c|c|}
\hline \multicolumn{9}{|c|}{ Panel regressions using $R G F$ components $\left(\gamma\right.$ and $\beta$ ) and $R G F^{L F}$ with ITO, IIO and VAX } & \multirow{2}{*}{ Table 7} \\
\hline & (1) & (2) & (3) & (4) & (5) & (6) & (7) & (8) & \\
\hline & $\gamma$ & $\beta$ & $\gamma$ & $\beta$ & $\gamma$ & $\beta$ & $\gamma^{L R}-\beta^{L R}$ & $\gamma^{L R}-\beta^{L R}$ & $\gamma^{L R}-\beta^{L R}$ \\
\hline \multirow[t]{2}{*}{ ITO } & $0.84^{\star \star *}$ & 0.15 & & & & & $0.08^{* * *}$ & & \\
\hline & [0.127] & {$[0.100]$} & & & & & [0.023] & & \\
\hline \multirow[t]{2}{*}{110} & & & $0.69^{\star \star \star}$ & $-0.24^{\star *}$ & & & & $0.25^{\star \star *}$ & \\
\hline & & & [0.132] & {$[0.114]$} & & & & {$[0.042]$} & \\
\hline \multirow[t]{2}{*}{ VAX } & & & & & -0.21 & $0.74^{\star * *}$ & & & $-0.31^{* * *}$ \\
\hline & & & & & {$[0.136]$} & {$[0.095]$} & & & {$[0.047]$} \\
\hline \multicolumn{10}{|c|}{ Model information } \\
\hline Fixed effects & Y & Y & Y & Y & Y & Y & Y & Y & Y \\
\hline FTO & Y & Y & Y & Y & $\mathrm{Y}$ & Y & Y & Y & Y \\
\hline Trend & $\mathrm{Y}$ & Y & $\mathrm{Y}$ & Y & Y & Y & $\mathrm{Y}$ & $\mathrm{Y}$ & Y \\
\hline $\mathrm{R}^{2}$ (overall) & 0.174 & 0.098 & 0.144 & 0.104 & 0.097 & 0.192 & 0.083 & 0.116 & 0.141 \\
\hline Observations & 1,800 & 1,800 & 1,800 & 1,800 & 1,800 & 1,800 & 1,800 & 1,800 & 1,800 \\
\hline $\begin{array}{l}\text { Number of } \\
\text { countries }\end{array}$ & 18 & 18 & 18 & 18 & 18 & 18 & 18 & 18 & 18 \\
\hline \multicolumn{10}{|c|}{$\begin{array}{l}\text { Notes: ITO = (exports + imports of intermediate goods and services)/GDP, IIO = (imports of intermediate goods and services)/GDP and, as defined } \\
\text { in Section } 2 \text { in the paper, the VAX is value-added of exports. For the construction of the dependent variables, see main text. In all specifications, the } \\
\text { sample runs from Q1 } 1982 \text { to Q4 2006. Bootstrapped standard errors in brackets; }{ }^{* * *} \text { denotes significance at the } 1 \% \text { level, }{ }^{* *} \text { at the } 5 \% \text { level, and * } \\
\text { at the } 10 \% \text { level. }\end{array}$} \\
\hline
\end{tabular}

\section{Conclusion}

Our evidence supports the view that the rise of GVCs has been a key factor behind the growing importance of the global output gap in determining domestic inflation.

18 Our findings thus contrast with Bianchi and Civelli (2015), who present evidence supporting the GI hypothesis but conclude that the conventional measure of trade openness does not increase sufficiently to explain the rise in the importance of global slack. 
We also find that controlling for the impact of GVCs, conventional measures of trade openness only have limited explanatory power. ${ }^{19}$

It is natural to think that a reason for this close link is the increased cross-border competition generated by the expansion of GVCs. The more easily measurable channel of this competition is through price pressures from inputs that are actually imported at all stages of the production process. The much harder-to-measure, but possibly even more important, channel works through the inputs that could potentially be imported at the various production stages (ie through the contestability of markets for goods and services). Unfortunately, our analysis cannot distinguish between the two. ${ }^{20}$ But more detailed GVC measures based on increasingly available intermediate trade data could eventually shed further light on these channels and help refine the analysis.

Our findings point to the need for further theoretical and empirical research on the globalisation of inflation hypothesis, especially on the role of GVCs. On the theoretical side, this raises questions about approaches that model inflation as largely a country-centric phenomenon and derive the corresponding policy implications. On the empirical side, questions remain about whether it would be possible to develop more informative measures of global slack that would reflect differences in the sectoral value-added content of trade rather than simply in its economy-wide content. For example, Auer et al (2016) provide a quantification of one specific channel of interest, finding that most of the international co-movement in producer price inflation can be attributed to input-output linkages. There is also a need to extend the analysis carried out in this paper to a consideration of alternative measures of domestic and global slack. The monetary policy implications of a greater role for global factors in determining domestic inflation would be far-reaching, as clearly these factors are beyond the control of individual central banks. Such implications cannot be ignored.

\section{References}

Auer, R and A Fischer (2010): "The effect of low-wage import competition on US inflationary pressure", Journal of Monetary Economics, vol 57, no 4, pp 491-503.

Auer, R, A Levchenko and P Sauré (2016): "International inflation spillovers via inputoutput linkages", mimeo, University of Michigan.

Auer, R and A Mehrotra (2014): "Trade linkages and the globalisation of inflation in Asia and the Pacific", Journal of International Money and Finance, vol 49, part A.

Auer, R and P Sauré (2013): "The globalisation of inflation: a view from the crosssection", in BIS Papers, no 70, February, pp 113-118.

19 This is not to say that conventionally measured trade and financial linkages have no impact on global price dynamics. For example, Auer and Fischer (2010), Hirakata et al (2014) and Bugamelli et al (2015) document substantial effects of final goods import competition from low wage countries, in particular, from China, on price dynamics in the United States and several other advanced economies. International financial connections appear to matter especially during economic and financial crises.

20 This greater competition in goods and services markets also has implications for factor input markets, notably for labour. Our findings are consistent with the secular decline in the bargaining power and strength of labour unions, which has gone hand-in-hand with a declining share of labour income. 
Baldwin, R (2014): "Misthinking globalisation: twentieth-century paradigms and twenty first-century challenges", Australian Economic History Review, vol 54, no 3, pp 212-219.

Bean, C (2006): "Impact of globalization on monetary policy: commentary", comments delivered at the Jackson Hole Economic Policy Symposium, Jackson Hole, Wyoming (an event sponsored by the Federal Reserve Bank of Kansas City), 26 August, pp 307316.

Bernanke, B (2007): "Globalization and monetary policy", speech at the Fourth Economic Summit, Stanford Institute for Economic Policy Research, 2 March.

Benigno, P and E Faia (2016): "Globalization, pass-through and inflation dynamics," International Journal of Central Banking, vol 12, no 4, pp 263-306.

Bianchi, F and A Civelli (2015): "Globalization and inflation: evidence from a time varying VAR", Review of Economic Dynamics, vol 18, no 2, pp 406-433.

Borio, C and A Filardo (2007): "Globalisation and inflation: new cross-country evidence of the global determinants of domestic inflation", BIS Working Papers, no 227.

Bugamelli, M, S Fabiani and E Sette (2015): "The age of the dragon: the effect of imports from China on firm-level prices", Journal of Money, Credit and Banking, vol 47, no 6, pp 1091-1118.

Burstein, A, C Kurz and L Tesar (2008): "Trade, production sharing, and the international transmission of business cycles," Journal of Monetary Economics, vol 55, no 4, pp 775-795.

Carney, M (2015): remarks delivered at the Jackson Hole Economic Policy Symposium, Jackson Hole, Wyoming (an event sponsored by the Federal Reserve Bank of Kansas City) and published in the Proceedings of the Economic Policy Symposium, 29 August, 437-454.

Caruana, J (2012): Speech at the CEMLA-SEACEN conference on "The role of central banks in macroeconomic and financial stability: the challenges in an uncertain and volatile world", Punta del Este, Uruguay, 16 November.

Ciccarelli, M and B Mojon (2010): "Global inflation", The Review of Economics and Statistics, vol 92, no 3, pp 524-535.

Draghi, M (2016): "How central banks meet the challenge of low inflation", Marjolin Lecture, Frankfurt, 4 February.

Engel, C (2013): "Inflation and globalisation: a modelling perspective", BIS Papers, no 70, February.

Fisher, R (2006): "Coping with globalization's impact on monetary policy", speech at the Allied Social Science Association Meetings, Boston, 6 January.

Fischer, S (2015): "US inflation developments", speech delivered at the Jackson Hole Economic Policy Symposium, Jackson Hole, Wyoming (an event sponsored by the Federal Reserve Bank of Kansas City), 29 August.

Galí, J (2010): "Inflation pressures and monetary policy in a global economy", International Journal of Central Banking, vol 6, no 1, pp 93-102.

Grossman, G and E Rossi-Hansberg (2008): "Trading tasks: a simple theory of offshoring", American Economic Review, vol 98, no 5, pp 1978-1997. 
Hirakata, N, Y Iwasaki and M Kawai (2014): "Emerging economies' supply shocks and Japan's price deflation: international transmissions in a three-country DSGE model", Asian Development Bank Working Papers, no 459.

Ihrig, J, S Kamin, D Lindner and J Marquez (2010): "Some simple tests of the globalization and inflation hypothesis", International Finance, vol 13, no 3, pp 343375.

Johnson, R and G Noguera (2012): "Accounting for intermediates: production sharing and trade in value added", Journal of International Economics, vol 86, no 2, pp 224236.

Johnson, R and G Noguera (2016): "Fragmentation and trade in value added over four decades," mimeo, Dartmouth College.

Jordan, T (2015): "The impact of international spillovers on Swiss inflation and the exchange rate", Journal of International Money and Finance, vol 68, no 1, pp 262-265.

Lane, P and G Milesi-Ferretti (2007): "The external wealth of nations mark II: revised and extended estimates of assets and liabilities, 1970-2004", Journal of International Economics, vol 73, no 2, pp 223-250.

Lombardo, G and F Ravenna (2014): "Openness and optimal monetary policy," Journal of International Economics, vol 93, no 1, pp 153-172.

Manopimoke, P (2016): "Globalization and international inflation dynamics: the role of the global output gap", Puey Ungphakorn Institute for Economic Research (Bank of Thailand) Discussion Papers, no 8.

Martínez-García, E and M Wynne (2013): "Global slack as a determinant of US inflation," in BIS Papers, vol 70, February, pp 93-98.

Martínez-García, E and M Wynne (2010): "The global slack hypothesis," Federal Reserve of Dallas Staff Papers, no 10.

Mumtaz, H and P Surico (2009): "The transmission of international shocks: a factoraugmented VAR approach", Journal of Money, Credit and Banking, vol 41, no s1, pp 71-100.

Mumtaz, H and P Surico (2012): "Evolving international inflation dynamics: world and country-specific factors", Journal of the European Economic Association, vol 10, no 4, pp 716-734.

Poloz, S (2016): "Cross-border trade integration and monetary policy", The Paul Storer Memorial Lecture, delivered at Western Washington University, Bellingham, Washington, 26 September.

Woodford, M (2010): "Globalization and monetary control", in J Galí and M Gertler (eds), International Dimensions of Monetary Policy, University of Chicago Press, pp 1377.

Wynne, M (2012): "Five years of research on globalization and monetary policy: what have we learned?", Federal Reserve Bank of Dallas Annual Report.

Yellen, J (2006): speech delivered at the "Euro and the dollar in a globalized economy" conference, Federal Reserve Bank of San Francisco, 27 May. 


\section{Appendix}

\section{Evolution of ITO and $F T O^{1}$}

Graph A1

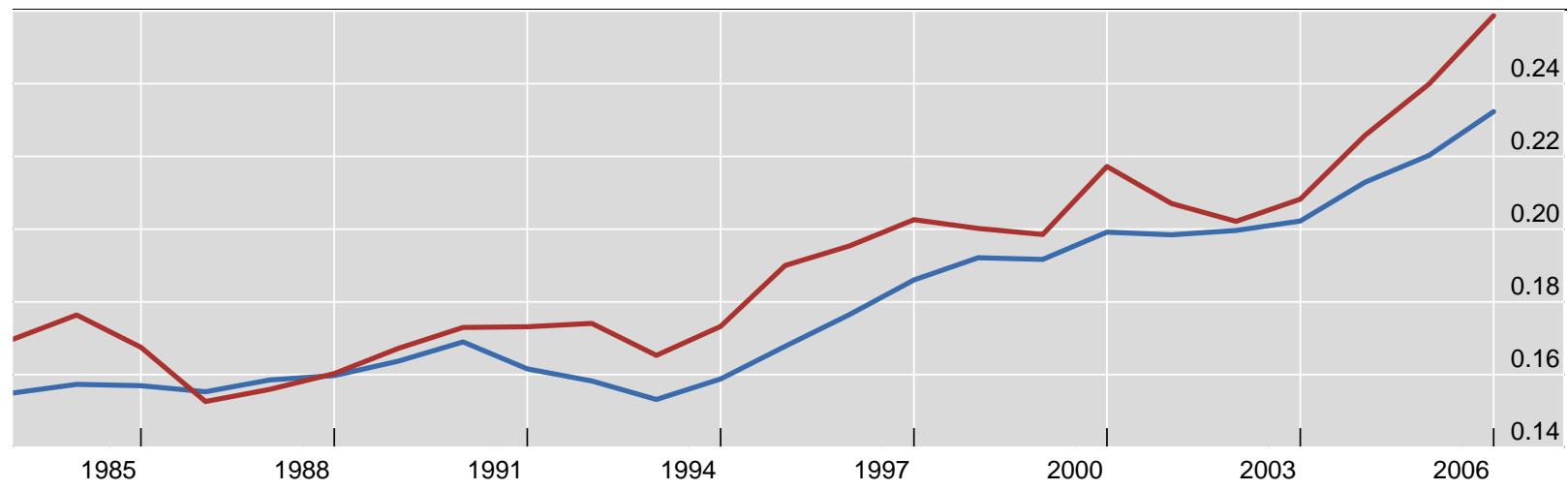

- ITO

FTO

1 The evolution of ITO = (exports + imports of intermediate goods and services)/GDP and FTO = (exports + imports of finals goods and services)/GDP for the years from 1983 to 2006. Each observation shows the cross-country average of ITO and FTO for 18 countries.

Source: authors' calculations based on Johnson and Noguera (2016).

Evolution of I/CS (left axis) and VAX (right axis) ${ }^{1}$

Graph A2

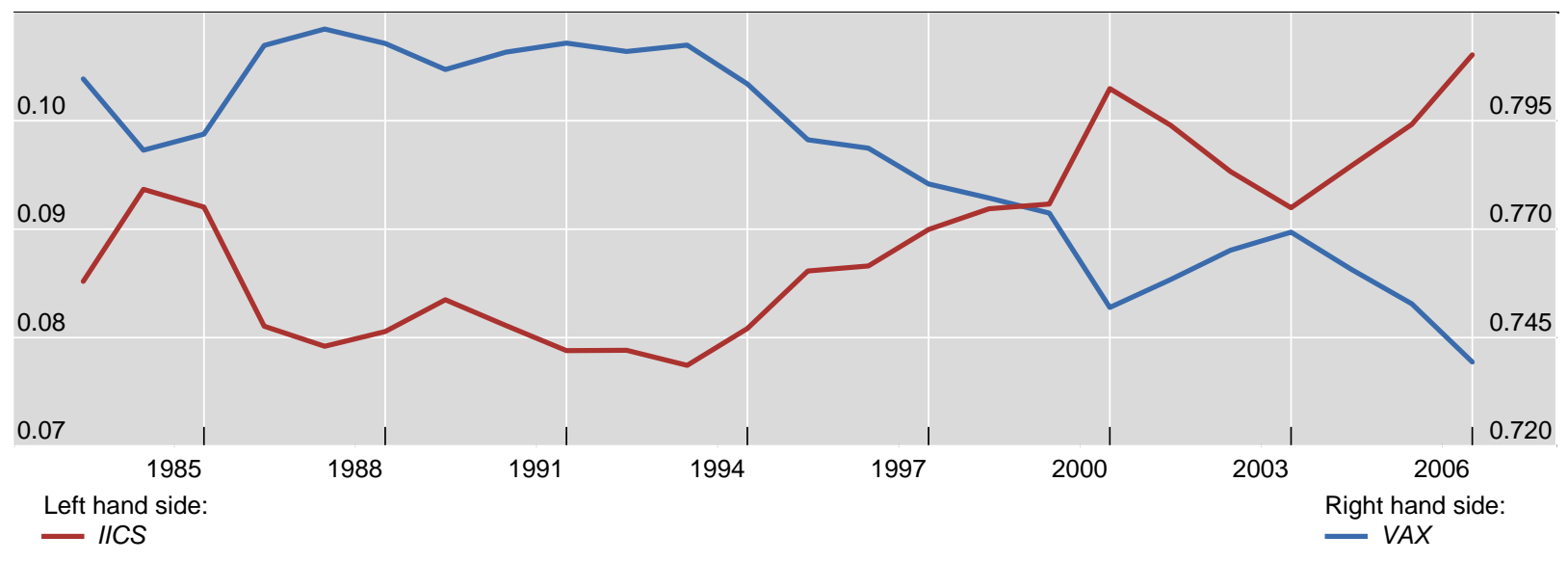

1 As defined in Section 2 in the paper, VAX is value-added exports and IICS is the production cost share of imported intermediate goods and services. The figure shows the evolution of VAX and IICS for the years from 1983 to 2006 . Each observation shows the cross-country average of the VAX (red line, right axis) and IICS (blue line, left axis) for 18 countries.

Source: authors' calculations based on Johnson and Noguera (2016). 


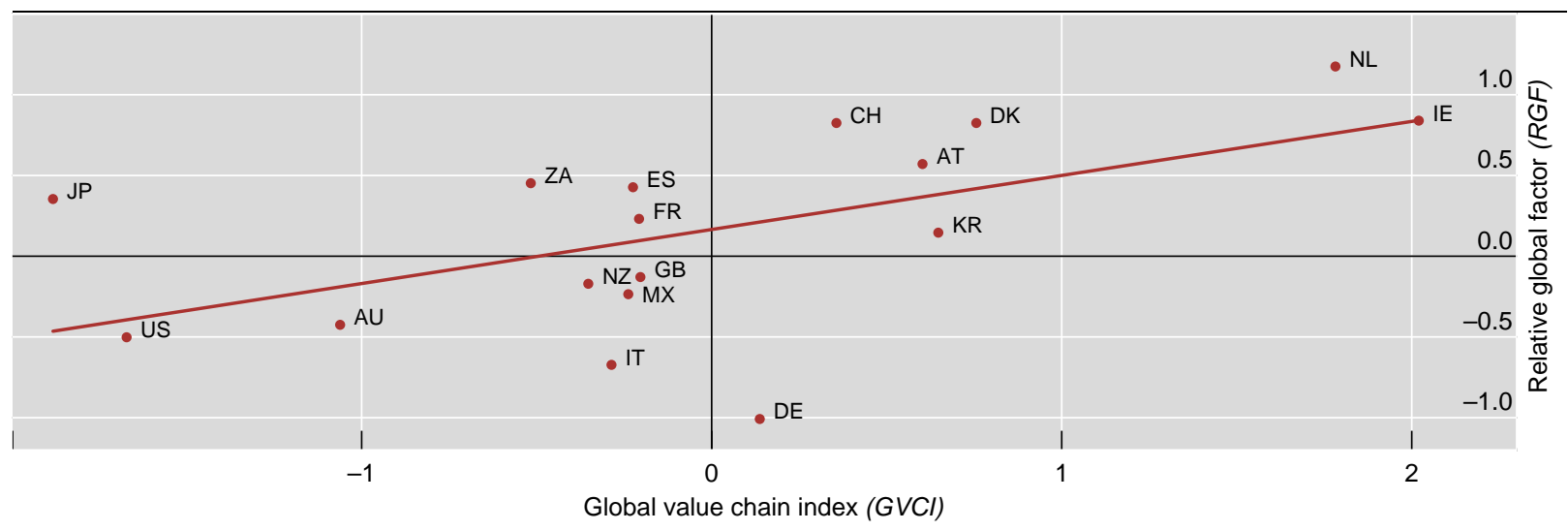

$\mathrm{AU}=$ Australia; $\mathrm{AT}=$ Austria; $\mathrm{CH}=$ Switzerland; $\mathrm{DE}=$ Germany; $\mathrm{DK}=$ Denmark; $\mathrm{ES}=$ Spain; FR = France; $\mathrm{GB}=$ United Kingdom; IE = Ireland; $\mathrm{IT}$ = Italy; JP = Japan; KR = Korea; MX = Mexico; NL = Netherland; NZ = New Zealand; US = United States; ZA = South Africa

${ }^{1} G_{V C I} I_{i, t}=I I C S_{i, t}-V A X_{i, t}$. The cross-country relationship between $\mathrm{GVCl}$ and the relative global factor (RGF) for 17 economies. Each observation shows the average of the GVCl and RGF from 1982 to 2006 . The red fitted line has a slope of 0.33 (significant at the $5 \%$ level). Canada $(R G F=-3.17, G V C l=0.34)$ is not included.

Source: authors' calculations.

GVCl and the explanatory power of global output gaps over time ${ }^{1}$

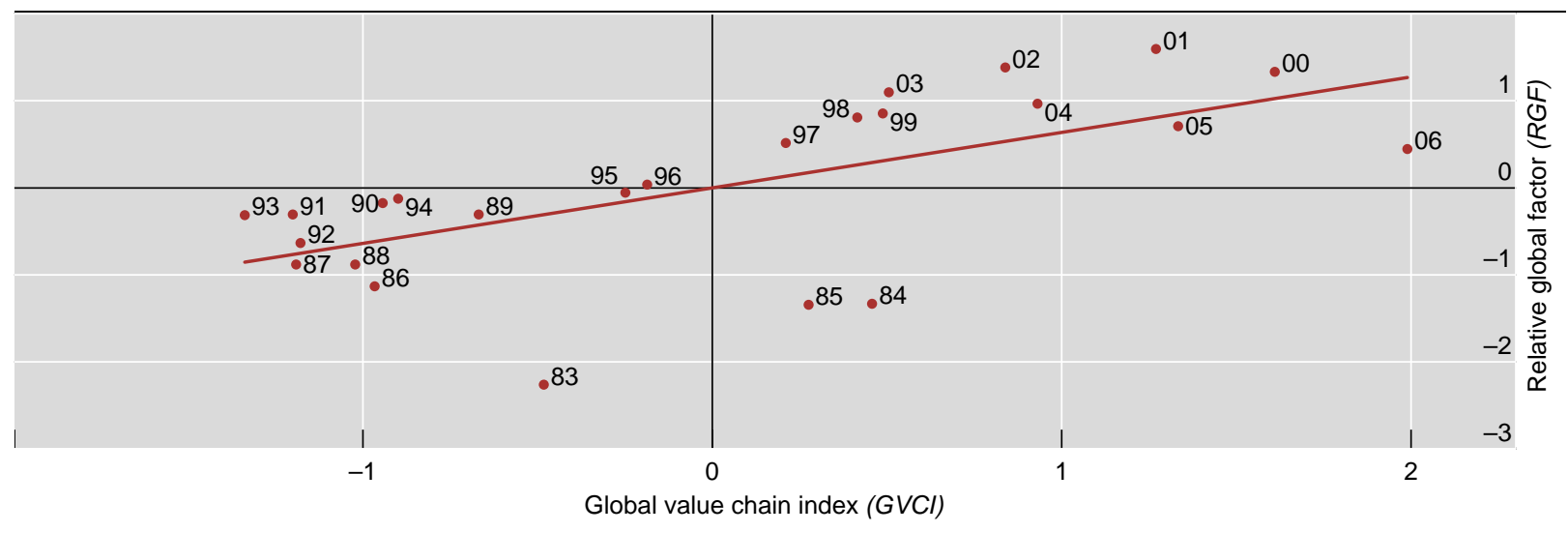

${ }^{1} G_{C V I} I_{i, t}=I I C S_{i, t}-V A X_{i, t}$. The relationship between $G V C l$ and the relative global factor (RGF) for the years from 1983 to 2006 . Each observation shows the cross-country average of GVCl and RGF in a given year for 18 countries. The red fitted line has a slope of 0.64 (significant at the $1 \%$ level).

Source: authors' calculations. 